\title{
Luteinization of bovine granulosa cells and corpus luteum formation associated with loss of androgen- aromatizing ability
}

\author{
K. M. Henderson* and Y. S. Moon $\dagger$ \\ Department of Obstetrics \& Gynaecology, University of Western Ontario, \\ University Hospital, London, Ontario, Canada N6A 5 A5
}

\begin{abstract}
Summary. The relative aromatizing ability of bovine luteinizing granulosa cells and dispersed luteal cells in tissue culture was studied. Luteinization of granulosa cells, as indicated by steadily increasing progesterone production (from 50 to $300 \mathrm{ng} / 10^{5}$ cells/day over 4-5 days), was accompanied by a dramatic reduction in their capacity to aromatize exogenous androgen; oestradiol- $17 \beta$ production falling from 200 to $<10 \mathrm{ng} / 10^{5}$ cells/day over $4-5$ days. Luteal cells also had only a very limited capacity to aromatize exogenous androgen, maximum oestradiol- $17 \beta$ production being $<600 \mathrm{pg} / 10^{5}$ cells/day. The loss in aromatizing capacity of granulosa cells during luteinization was also reflected in the relative endogenous steroid content of non-luteinized granulosa cells and luteal tissue, the former containing high levels of oestradiol- $17 \beta, \leqslant 28 \mathrm{ng} / \mathrm{mg}$ protein, while the latter, although containing substantial amounts of testosterone, $\leqslant 5.7 \mathrm{ng} / \mathrm{g}$ tissue, contained very little oestradiol- $17 \beta, \leqslant 0.35$ $\mathrm{ng} / \mathrm{g}$ tissue. These findings suggest that luteinization of bovine granulosa cells and subsequent corpus luteum formation is associated with a loss in androgen aromatase activity.
\end{abstract}

\section{Introduction}

Studies in several species indicate that while follicular granulosa cells have only a very limited capacity to synthesize androgens (Bjersing \& Carstensen, 1967; Channing, 1969; Lacroix, Eechaute \& Leusen, 1974; Fortune \& Armstrong, 1977; Fowler, Fox, Edwards, Walters \& Steptoe, 1978), they can, under the influence of follicle-stimulating hormone (FSH), readily aromatize androgens to oestradiol-17 $\beta$ (Dorrington, Moon \& Armstrong, 1975; Moor, 1977; Fortune \& Armstrong, 1978). It has therefore been suggested that granulosa cells may contribute to follicular oestradiol-17 $\beta$ production through aromatization of androgens secreted by other ovarian compartments, in particular thecal tissue (see review by Armstrong \& Dorrington, 1977). Little, however, is known of the way in which the aromatizing capacity of granulosa cells is affected by their luteinization during corpus luteum formation. The purpose of the present investigation was to study and compare androgen aromatization by bovine granulosa cells undergoing luteinization in vitro, and by dispersed bovine luteal cells in vitro.

\section{Radioimmunoassay of culture medium}

The progesterone content of the culture medium was assayed directly by radioimmunoassay (RIA), utilizing the antibody and methods described previously by Orczyk, Hichens, Arth \& Behrman (1974). The antiserum was prepared against 11 $\alpha$-hydroxyprogesterone hemisuccinate

\footnotetext{
* Present address: Department of Biochemistry, University of Edinburgh Medical School, Teviot Place, Edinburgh, EH8 9AG, Scotland, U.K.

$\dagger$ Present address: Department of Obstetrics \& Gynaecology, Ottawa Civic Hospital, Carling Avenue, Ottawa, Ontario, Canada.
} 
conjugated to bovine serum albumin (BSA). The antiserum showed negligible cross-reactivity $(<0.1 \%)$ with androgens and oestrogens. The validity of direct assay of culture medium was checked by comparing values obtained by this method with values for petroleum ether-extracted aliquots taken from the same samples. Regression analysis of the results gave the equation $y=$ $0.90 x-13.37$, the coefficient of linear correlation being $0.98(n=19)$. The limit of sensitivity of the assay was $25 \mathrm{pg}$ per tube. Oestradiol-17 $\beta$ and oestrone were measured in diethyl etherextracted aliquots of culture media by RIA using antisera and methods described and validated previously by Dorrington \& Armstrong (1975) and Dorrington, Fritz \& Armstrong (1976) respectively. The oestradiol-17 $\beta$ antiserum was raised against oestradiol-17\%-6-carboxymethyl oxime-BSA and the oestrone antiserum against oestrone-6-(O-carboxymethyl) oxime-BSA. Both antisera had low cross-reactivity $(<10 \%)$ with other phenolic steroids and negligible cross reactivity $(<0.1 \%)$ with neutral steroids. The limit of sensitivity of both oestrogen assays was 5 pg per tube. The intra- and inter-assay coefficients of variation of all the above assays were $<10 \%$.

\section{Culture of granulosa cells}

Bovine ovaries were obtained from cattle within $1 \mathrm{~h}$ of their slaughter at a local abattoir and transported to the laboratory in chilled Minimum Essential Medium (Modified) with Earle's Salts (EMEM) and supplemented with HEPES buffer (20 mM), glutamine (2 mM), penicillin (50 units $/ \mathrm{ml})$, streptomycin $(50 \mu \mathrm{g} / \mathrm{ml})$, amphotericin B $(0.625 \mu \mathrm{g} / \mathrm{ml})$ and non-essential amino acids (all reagents obtained from Flow Laboratories, Mississauga, Ontario, Canada). Large antral follicles (7-15 $\mathrm{mm}$ in diameter) were dissected out, the follicle wall slit open and the granulosa cells gently scraped with a platinum loop into chilled EMEM, supplemented as above. The harvested cells were pooled, washed three times with the above medium and an aliquot was taken to determine total cell number using a haemocytometer, and cell viability using nigrosin dye. Each dish contained 1.5-2.0 $\times 10^{5}$ 'live' cells which were cultured at $36^{\circ} \mathrm{C}$ in a humidified incubator on $15 \mathrm{~mm}$-diameter round plastic coverslips (Thermanox: Lux Scientific Corp., California, U.S.A.) in $1 \mathrm{ml}$ culture medium consisting of $10 \%(\mathrm{v} / \mathrm{v})$ fetal bovine serum and $90 \%$ EMEM without HEPES buffer but otherwise supplemented with glutamine, antibiotics and nonessential amino acids as described above. The gas phase was $5 \% \mathrm{CO}_{2}: 95 \%$ air. Exogenous testosterone or androstenedione (both from Sigma) was added daily throughout the culture period as $10 \mathrm{ng}$ to $1 \mu \mathrm{g}$ in $10 \mu \mathrm{l}$ ethanol, control cultures receiving $10 \mu \mathrm{l}$ ethanol only. The culture medium was replaced daily and stored at $-20^{\circ} \mathrm{C}$ until RIA of steroids. At the end of the culture period the cells were washed and stained with haematoxylin and eosin. The number of cells remaining was estimated by counting the number of cells within a $0.3 \mathrm{~mm}^{2}$ area at 12 sampling points on the coverslip, the total number of cells being estimated by extrapolation. Luteinization of the granulosa cells was indicated by a sustained production of progesterone accompanied by cellular hyperplasia and hypertrophy with an increase in the cytoplasm : nucleus ratio.

\section{Cell and organ culture of luteal tissue}

Cell culture. Individual bovine corpora lutea (CL) were enucleated from ovaries obtained from cattle within $1 \mathrm{~h}$ of their slaughter at a local abattoir. The CL were freed of adherent connective tissue and chopped into pieces approximately $2 \mathrm{~mm}$ in diameter in Hanks' Balanced Salt Solution without magnesium and calcium (Flow Laboratories, Mississauga, Ontario, Canada), and supplemented with HEPES (20 mM), glutamine $(2 \mathrm{~mm})$, and antibiotics as described above (HBS-HGA). The chopped tissue was washed twice with chilled HBS-HGA and incubated for $20 \mathrm{~min}$ at $37^{\circ} \mathrm{C}$ with stirring in HBS-HGA containing $0.2 \%$ collagenase (Type II, Sigma). The medium was decanted and the released cells were collected by lowspeed centrifugation and stored at $4^{\circ} \mathrm{C}$ in $\mathrm{HBS}-\mathrm{HGA}$. The remaining fragile tissue fragments were reincubated in $0.2 \%$ collagenase in $\mathrm{HBS}-\mathrm{HGA}$ at $37^{\circ} \mathrm{C}$ and final dispersal of cells was achieved by drawing through a $2 \mathrm{ml}$ syringe tip and a series of needles (18-22 gauge), the cells 
being collected by centrifugation. All the released cells were pooled together, filtered through 2 layers of sterile gauze and washed 4 times to remove any traces of collagenase. After estimating cell number and cell viability as above, cultures of $1.5-2.0 \times 10^{5}$ 'live' cells $(10-30 \mu \mathrm{m}$ in diameter) were set up exactly as described for the granulosa cells. At the end of the culture period, the number of cells remaining was estimated as described for the granulosa cells.

The age of the CL was estimated from their gross morphological appearance and by histological examination (Donaldson \& Hansel, 1965).

Organ culture. Bovine luteal tissue fragments approximately $2 \mathrm{~mm}$ in diameter were prepared as above. Cultures were initiated by placing 3 or 4 of the tissue fragments on a $25 \mathrm{~mm}$ diameter Millipore filter, pore size $0.45 \mu \mathrm{m}$, floating in $1 \mathrm{ml}$ culture medium contained in a Petri dish. The culture medium and incubation conditions were as described for the granulosa cells. At the end of the culture period the tissue fragments were taken up in $1 \mathrm{M}$-sodium hydroxide for subsequent protein determination by the method of Lowry, Rosebrough, Farr \& Randall (1951).

\section{Extraction of steroids from granulosa cells and luteal tissue}

Granulosa cells were harvested from individual large antral follicles (7-15 mm diameter) as described above. An aliquot of the cells was taken up in $1 \mathrm{ml} \mathrm{NaOH}$ for subsequent protein determination (Lowry et al., 1951). The remaining cells were homogenized in $1.5 \mathrm{ml}$ redistilled ethanol using a glass/glass homogenizer and shaken for $4 \mathrm{~h}$ at room temperature $\left(\sim 20^{\circ} \mathrm{C}\right)$. The cellular debris was separated by centrifugation, the supernatant removed and the remains reincubated in $1 \mathrm{ml}$ redistilled ethanol for a further $1 \mathrm{~h}$ at room temperature with shaking, before being left to stand overnight at $4^{\circ} \mathrm{C}$. The cellular debris was again separated, the supernatant removed, combined with the earlier one, the volume adjusted to $4 \mathrm{ml}$ and stored at $-20^{\circ} \mathrm{C}$ until assayed. Individual CL dissected free of connective tissue were minced, and approximately $1.5 \mathrm{~g}$ amounts were homogenized as above in $10 \mathrm{ml}$ redistilled ethanol. The remainder of the procedure was as described for the granulosa cells except that the second incubation volume of ethanol was $5 \mathrm{ml}$, and that after pooling the two supernatants, the final volume was adjusted to $20 \mathrm{ml}$.

Aliquots of the ethanolic extractions of the granulosa cells and CL were assayed for oestradiol-17 $\beta$ and testosterone by RIA after column chromatography on Sephadex LH-20 as described by Carr, Mikhail \& Flickinger (1971). Testosterone was separated using the solvent system hexane : benzene :methanol $(80: 10: 10$ by vol.) while oestradiol $-17 \beta$ was separated using benzene:methanol $(85: 15 \mathrm{v} / \mathrm{v})$. Recovery was estimated by the addition of 2000 c.p.m. $\mid 2,4,6,7,16,17-{ }^{3} \mathrm{H}$ loestradiol- $17 \beta$ (sp. act. $151 \mathrm{Ci} / \mathrm{mmol}$ : New England Nuclear), or 2000 c.p.m. $\left\{1,2,6,7-{ }^{3} \mathrm{H}\right\}$ testosterone (sp. act. $90 \mathrm{Ci} / \mathrm{mmol}$ : New England Nuclear) to the ethanolic aliquots before chromatography. The oestradiol-17 $\beta$ RIA was as described above. The testosterone RIA was carried out using an antiserum and methods previously described and validated by Auletta, Caldwell \& Hamilton (1974). The antiserum was raised against testosterone-3-carboxymethyloxime-BSA and cross-reacted (testosterone $100 \%$ ) with $5 \alpha$-reduced androstanes as follows:

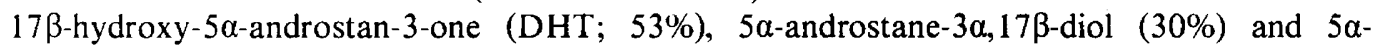
androstane-3 $\beta, 17 \beta$-diol $(13 \%)$. The antiserum showed negligible cross-reactivity $(<0 \cdot 1 \%)$ with oestrogens and progesterone. The level of sensitivity of this assay was $12 \mathrm{pg} /$ tube and the intraand inter-assay coefficients of variations were each $<12 \%$.

\section{Results}

\section{Morphological appearance of dispersed bovine luteal cells}

The typical histological appearance of the collagenase dispersed luteal cells is shown in Plate 1. At least two different cell types were present: (a) large spherical cells having a granular, highly eosinophilic cytoplasm, small prominent nuclei, and diameters in the range 10-30 $\mu \mathrm{m}$, and (b) small epithelial-type cells with no distinguishing morphological characteristics and $<5 \mu \mathrm{m}$ in diameter. 


\section{Androgen aromatization by luteinizing granulosa cells}

Table 1 shows oestradiol-17 $\beta$ and progesterone production in response to various concentrations of testosterone during Day 1 and Day 4 of culture. Large amounts of oestradiol-17 $\beta$ were produced in a dose-dependent fashion in response to the added testosterone during Day 1 of culture. By Day 4 there was a dramatic, significant reduction in the ability of the cells to produce oestradiol-17 $\beta$ in response to all the concentrations of added testosterone $(P<0.01$, Student's $t$ test). In contrast to this fall in oestradiol-17ß production, there was a significant $(P<0.01$, Student's $t$ test) 7 -fold increase in progesterone production by the luteinizing granulosa cells, the levels rising from about $35 \mathrm{ng} / 10^{5}$ cells on Day 1 to about $250 \mathrm{ng} / 10^{5}$ cells on Day 4 of culture. Testosterone had no effect on progesterone production $(P>0.05$, Student's $t$ test). Similar results, from a separate experiment, are shown in Text-figs 1 (a) and 1(b): the loss in aromatizing capacity was not due to a change in substrate specificity, there being a similar loss in the capacity of the luteinizing granulosa cells to aromatize both testosterone and androstenedione. Moreover, androstenedione was aromatized less effectively than testosterone, there being significantly less oestradiol-17 $\beta$ produced in response to androstenedione during Days 1 and 2 of culture than to the same concentration of testosterone $(P<0.02$, Student's $t$ test). The fall in oestradiol-17 $\beta$ production throughout the culture period could not be accounted for by any increase in oestrone production, the oestrone levels in the androgen-treated cultures at all times being only $7-11 \%$ of those of oestradiol-17 $\beta$. No detectable oestrone was present in the control cultures. Neither could the loss in aromatizing capacity be explained by changes in cell numbers, since the number of cells remaining in the androgentreated cultures at the end of the culture period was $69-77 \%$ of the starting number. This apparent decline in the cell number over the culture period may be due to the different methods of estimating cell numbers at the start and finish of the culture period. The daily addition of gonadotrophins (250 ng NIH-FSH-S11/ml and $250 \mathrm{ng} \mathrm{NIH-LH-B8/ml)} \mathrm{had} \mathrm{no}$ effect on progesterone or oestradiol- $17 \beta$ production by either the control or androgen-treated cultures. However, it is possible that endogenous gonadotrophins present in the culture medium derived from the calf serum, or the high concentrations of gonadotrophins found in bovine follicular fluid (ranges: $2 \cdot 2-9.0 \mathrm{ng} \mathrm{LH} / \mathrm{ml}, n=80 ; 34-200 \mathrm{ng} \mathrm{FSH} / \mathrm{ml}, n=70: \mathrm{K}$. M. Henderson \& A. S. McNeilly, unpublished observations), may have been sufficient to stimulate maximally steroid production by the cells.

Table 1. The effect of testosterone (added daily) on the production (mean \pm s.d. of 4 replicate cultures) of oestradiol- $17 \beta$ and progesterone

by bovine granulosa cells during Days 1 and 4 of culture

\begin{tabular}{|c|c|c|c|c|}
\hline \multirow{2}{*}{$\begin{array}{l}\text { Testosterone } \\
\text { conc. (ng/ml) }\end{array}$} & \multicolumn{2}{|c|}{ Oestradiol-17 $\beta$ (ng/ $10^{5}$ cells) } & \multicolumn{2}{|c|}{ Progesterone $\left(\mathrm{ng} / 10^{5}\right.$ cells) } \\
\hline & Day 1 & Day 4 & Day 1 & Day 4 \\
\hline 0 & $0.45 \pm 0.05$ & N.D. & $38 \pm 5$ & $248 \pm 24$ \\
\hline 10 & $3 \cdot 6 \pm 0.4$ & $0.14 \pm 0.03$ & $40 \pm 4$ & $251 \pm 11$ \\
\hline 50 & $13.5 \pm 2.2$ & $0.26 \pm 0.02$ & $32 \pm 7$ & $240 \pm 34$ \\
\hline 100 & $33 \pm 4$ & $0.32 \pm 0.03$ & $29 \pm 6$ & $260 \pm 29$ \\
\hline 500 & $112 \pm 9$ & $0.57 \pm 0.06$ & $35 \pm 5$ & $251 \pm 28$ \\
\hline 1000 & $131 \pm 15$ & $0.78 \pm 0.04$ & $34 \pm 5$ & $234 \pm 36$ \\
\hline
\end{tabular}

N.D., not detectable.

Androgen aromatization by bovine luteal tissue

Luteal cell cultures. Text-figures $1(\mathrm{c})$ and $1(\mathrm{~d})$ show typical progesterone and oestradiol$17 \beta$ production by control and testosterone $(1 \mu \mathrm{g} / \mathrm{ml} /$ day $)$-treated cultures of luteal cells prepared from $\mathrm{CL}$ judged to be less than about 5 days old on the basis of morphological and histological characteristics as described by Donaldson \& Hansel (1965). Progesterone 


\section{PLATE 1}

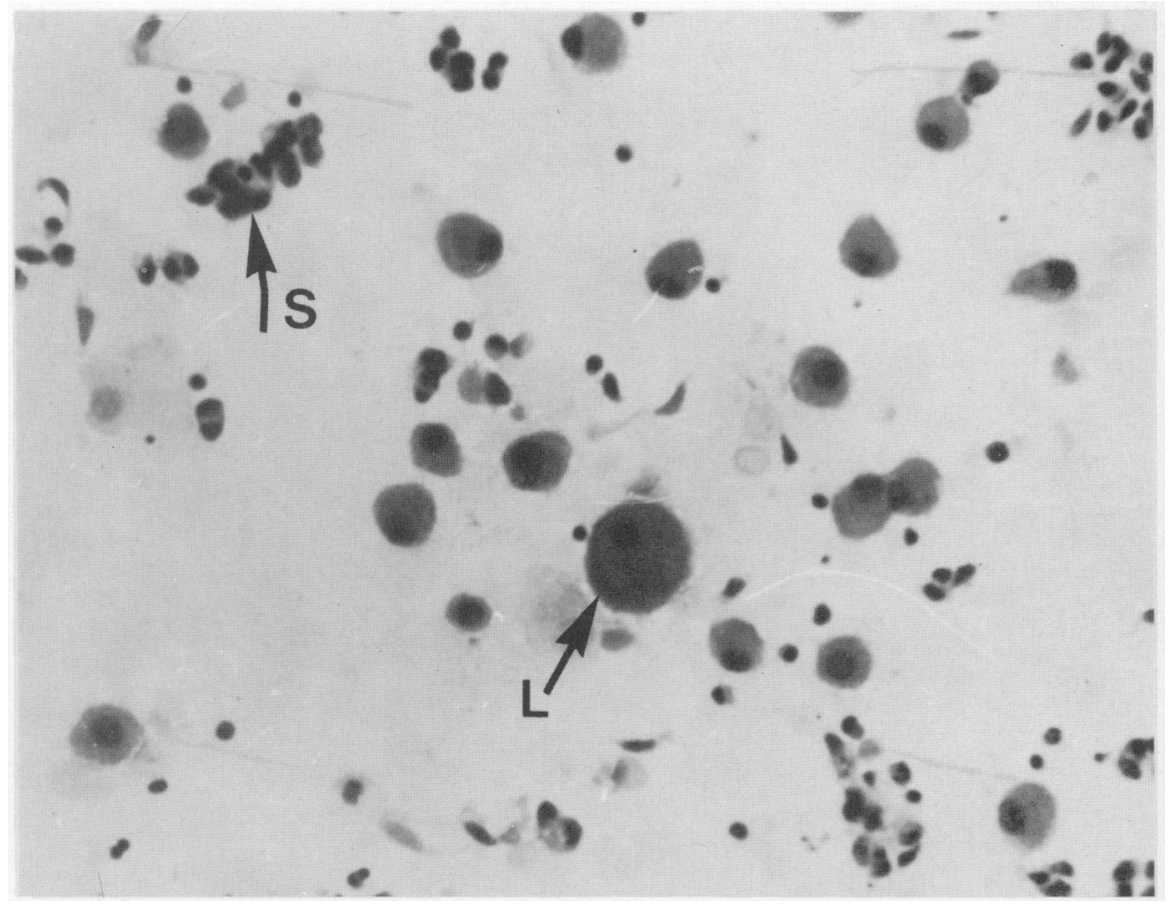

Haematoxylin-eosin stained smear of dispersed bovine luteal cells. $\mathrm{L}=$ large luteal cells, $10-30 \mu \mathrm{m}$ in diameter; $\mathrm{S}=$ small luteal cells, $<5 \mu \mathrm{m}$ in diameter. $\times 350$. 

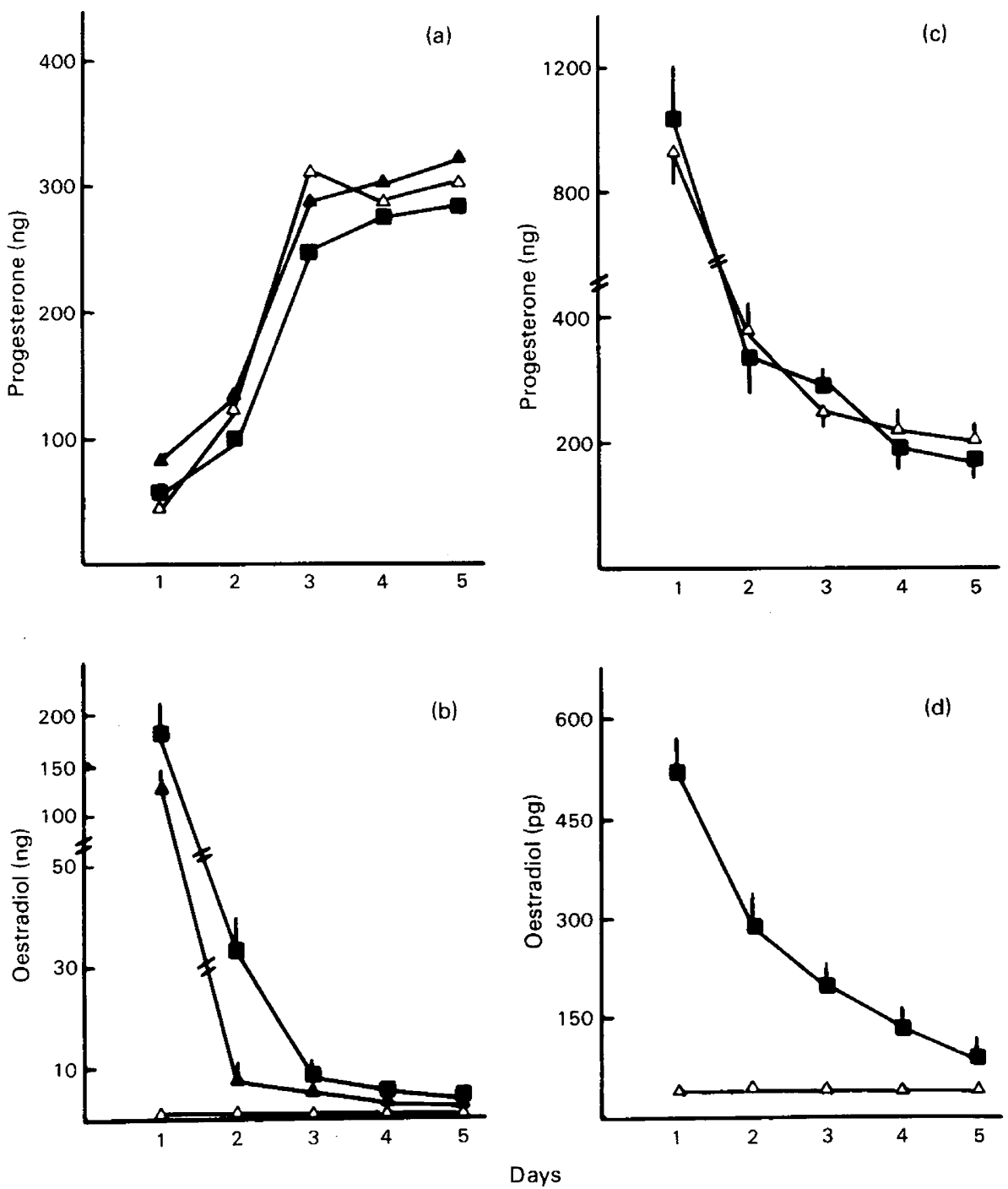

Text-fig. 1. The production (mean \pm s.d. for $n=5$ ) of progesterone (a, c) and oestradiol- $17 \beta$ (b, d) by bovine luteinizing granulosa cells $(a, b)$ and dispersed luteal cells $(c, d)$ in culture with different substrates added daily. All values are for $10^{s}$ cells/day. $\Delta$, No addition; $\mathbf{\square}$, testosterone, $1 \mu \mathrm{g} ; \Delta$, androstenedione, $1 \mu \mathrm{g}$. The s.d. lines have been omitted in (a) for clarity, but no significant differences between the groups were observed at any of the 5 days of culture $(P>$ $0 \cdot 05$, Student's $t$ test).

production by the luteal cells was maximal on Day 1 but declined thereafter. Examination of the cell types present throughout the culture period revealed that the large luteal cells did not survive well but died, as indicated by the presence of large luteal cells with broken plasma membranes, during the first $48-72 \mathrm{~h}$ of culture. In contrast, the small luteal cells underwent hyperplasia and hypertrophy. If the large luteal cells were the principal source of progesterone synthesis, which would be consistent with their morphological appearance, then the decline in progesterone would be compatible with their death.

Significant amounts of oestradiol-17 $\beta$ were produced by luteal cells only in the presence of added androgen. However, the maximum amount of oestradiol-17 $\beta$ produced was very low 
(approx. $500 \mathrm{pg} / 10^{5}$ cells) compared to the amounts produced by the granulosa cells before their luteinization (approx. $200 \mathrm{ng} / 10^{5}$ cells). Like progesterone production, oestradiol-17 $\beta$ production by the luteal cells fell during the culture period. No detectable oestrone was produced by the luteal cells. While low amounts of oestradiol-17 $\beta$ were produced in response to added testosterone in cultures prepared from newly formed CL, i.e. those estimated to be less than about 5 days old, there was no measurable oestradiol- $17 \beta$ or oestrone produced in response to added testosterone ( $1 \mu \mathrm{g} / \mathrm{ml} /$ day) by cultures prepared from older CL.

Organ cultures. To test the possibility that the low aromatizing capacity of the bovine luteal cells might be an artefact of the preparative procedure, androgen aromatization by bovine luteal tissue in organ culture was studied. Table 2 shows daily progesterone and oestradiol-17 $\beta$ production, in the presence and absence of testosterone, by tissue taken from a newly formed CL and cultured for 2 days. The findings are similar to those obtained with the luteal cells, in that oestradiol- $17 \beta$ was produced only in the presence of added androgen, and the amounts produced were very low, relative to progesterone production. As in the studies with luteal cells, steroid production was reduced during the 2 nd day of culture. The daily addition of gonadotrophins had little effect on either progesterone or oestradiol-17 $\beta$ production. No detectable oestradiol-17 $\beta$ was produced in similar organ culture studies with CL estimated to be more than about 1 week old.

\section{Testosterone and oestradiol-17 $\beta$ content of granulosa cells and luteal tissue}

The loss in aromatizing capacity of granulosa cells during luteinization, observed in the culture studies, was also reflected in the endogenous concentrations of testosterone and oestradiol-17 $\beta$ found in the non-luteinized granulosa cells, measured at the time of collection, and in CL. While the granulosa cells contained substantial amounts (ng/mg protein) of both testosterone $(0 \cdot 17-8 \cdot 6, n=10)$, and oestradiol-17 $\beta(2 \cdot 0-28, n=10)$, reflecting an active aromatase system, the luteal tissue, although containing appreciable amounts (ng/g tissue) of testosterone $(1 \cdot 6-5 \cdot 7, n=8$ ), contained only extremely small amounts of oestradiol-17 $\beta$ (not detectable- $0.35, n=8$ ), reflecting a relatively inactive aromatase system.

Table 2. The production (mean \pm s.d. of 4 replicate cultures) of oestradiol-17 $\beta$ and progesterone by newly formed ( $<5$ days) bovine CL in organ culture

\begin{tabular}{|c|c|c|c|c|}
\hline \multirow[b]{2}{*}{ Treatment (daily) } & \multicolumn{2}{|c|}{ Day 1} & \multicolumn{2}{|c|}{ Day 2} \\
\hline & $\begin{array}{l}\text { Progesterone } \\
\text { (ng/mg protein) }\end{array}$ & $\begin{array}{r}\text { Oestradiol- } 17 \beta \\
\text { (pg/mg protein) }\end{array}$ & $\begin{array}{l}\text { Progesterone } \\
\text { (ng/mg protein) }\end{array}$ & $\begin{array}{l}\text { Oestradiol- } 17 \beta \\
\text { (pg/mg protein) }\end{array}$ \\
\hline None & $515 \pm 45$ & N.D. & $281 \pm 40$ & N.D. \\
\hline Testosterone* & $525 \pm 63$ & $353 \pm 28$ & $222 \pm 64$ & $269 \pm 26$ \\
\hline $\mathrm{LH} \dagger+$ testosterone* & $597 \pm 110$ & $285 \pm 57$ & $272 \pm 76$ & $238 \pm 49$ \\
\hline 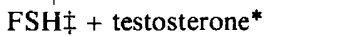 & $551 \pm 78$ & $356 \pm 30$ & $301 \pm 36$ & $251 \pm 56$ \\
\hline $\mathrm{LH}_{\dagger}+\mathrm{FSH} \ddagger+$ testosterone ${ }^{*}$ & $678 \pm 93$ & $414 \pm 70$ & $372 \pm 47$ & $306 \pm 37$ \\
\hline
\end{tabular}

N.D., not detectable.

$* 1 \mu \mathrm{g} / \mathrm{ml}$.

$\dagger 0.25 \mu \mathrm{g} \mathrm{NIH-LH}-\mathrm{B} 8 / \mathrm{ml}$.

$\ddagger 0.25 \mu \mathrm{g}$ NIH-FSH-S $11 / \mathrm{ml}$.

\section{Discussion}

While bovine non-luteinized follicular granulosa cells can readily aromatize exogenous androgen to oestradiol-17 $\beta$ (Lacroix et al., 1974), the above studies with granulosa cells undergoing luteinization in tissue culture suggest that this capacity rapidly declines as the cells luteinize. This finding is unlikely to be an artefact of the particular culture system used, since bovine luteal tissue, 
of which luteinized granulosa cells constitute a major portion, also had only a very limited capacity to aromatize exogenous androgen. Moreover, the relative amounts of oestradiol-17 $\beta$ found in non-luteinized follicular granulosa cells and luteal tissue are also consistent with a reduction in aromatase activity as the granulosa cells luteinize during corpus luteum formation. It could be argued, however, that the endogenous steroid content of the granulosa cells might not necessarily reflect steroidogenesis by the cells, some of the steroids possibly diffusing in from follicular theca cells. This possibility may account for the high levels of testosterone found in the granulosa cells, since bovine granulosa cells have only a very limited capacity to synthesize androgen, while the theca cells can readily synthesize testosterone (Lacroix et al., 1974). It is likely, however, that the oestradiol-17 $\beta$ found in the granulosa cells originated from androgen aromatization in these cells, since theca cells have only a relatively weak aromatase enzyme system (Lacroix et al., 1974). Bovine luteal tissue, although containing appreciable amounts of testosterone, contained extremely low amounts of oestradiol-17 $\beta$, indicating very low aromatase activity relative to the granulosa cells, which is consistent with the findings of the culture studies. This is also compatible with the early findings of Savard \& Telegdy (1965) who used short-term incubation studies of bovine luteal tissue with ${ }^{14} \mathrm{C}$-labelled radioactive precursors and concluded that the bovine $\mathrm{CL}$ completely lacked any aromatase activity. Using more sensitive techniques of cell culture combined with RIA, however, it was possible, in the present study, to demonstrate limited aromatase activity providing the $\mathrm{CL}$ were newly formed, i.e. less than about 5 days old. Maximum progesterone production by the dispersed luteal cells during Day 1 of culture was 3 times greater than the maximum amount produced by the luteinized granulosa cells. This suggests that while the granulosa cells luteinized to a certain extent in vitro, luteinization was not complete. Incomplete luteinization might also explain why the luteinized granulosa cells, although having a much reduced aromatase activity than before luteinization, still had a greater aromatase activity than the luteal cells. Progesterone secretion by the luteal cells declined rapidly during culture, probably due to the death of the large cells which had the morphological characteristics of steroid-secreting cells. Why the large luteal cells failed to survive in culture is uncertain, although it is possible that being highly differentiated they were merely less able to adapt to the culture conditions than the less well differentiated granulosa cells. The role of the small luteal cells is also uncertain. While these cells survived well in culture they did not appear to contribute towards steroid secretion, as indicated by the declining levels of progesterone and oestradiol-17ß.

The culture conditions seem to be important for demonstrating this loss in aromatizing activity of the granulosa cells during luteinization. In a previous study utilizing bovine granulosa cells from similarly sized follicles, this loss in aromatase activity was not observed (Henderson \& Swanston, 1978). These former studies, however, utilized different culture conditions; the culture medium was Medium 199 supplemented with HEPES buffer and contained $20 \%$ donor calf serum with air as the gas phase. Under these conditions, the maximum amount of oestradiol-17 $\beta$ which could be produced in response to exogenous androgen was only $200-400 \mathrm{pg} / 10^{5}$ cells/day. In view of the much greater levels found in the present study, both before and after luteinization, it is possible that the former culture conditions were less favourable for oestradiol$17 \beta$ production, thereby masking any loss in aromatase activity.

In contrast to the bovine $C L$ which seems to lose completely its capacity to synthesize oestradiol-173, human and porcine CL do synthesize oestradiol-17 $\beta$ (Hammerstein, Rice \& Savard, 1964; Watson \& Leask, 1975). Preliminary findings, however, utilizing human and porcine ovarian cells in tissue culture, suggest that the aromatase activity of the granulosa cell of these species is much greater than that of luteal cells (K. M. Henderson, Y. S. Moon \& B. K. Tsang, unpublished data). Thus, in these species also, luteinization of granulosa cells and subsequent corpus luteum formation may be associated with a reduction, if not a complete loss, in aromatase activity. The mechanism by which the aromatizing capacity of the bovine granulosa cells is lost during luteinization is uncertain. However, the bovine CL, although 
containing substantial amounts of mitochondrial cytochrome P-450, contains relatively little microsomal cytochrome P-450 (McIntosh, Uzgiris, Alonso \& Salhanick, 1971). Microsomal cytochrome P-450 is required for androgen aromatization (Savard, 1973). Thus, a loss in microsomal cytochrome P-450 together with a rise in mitochondrial cytochrome P-450 could account for the fall in aromatizing capacity but the rise in progesterone production occurring during luteinization and subsequent corpus luteum formation. This possibility is currently under investigation.

In conclusion, while functional luteinization of granulosa cells has generally been defined only in terms of increasing progesterone production, this study suggests that, at least for bovine granulosa cells, functional luteinization should perhaps also be defined in terms of decreasing androgen aromatizing capacity.

We are grateful to Dr D. T. Armstrong for providing laboratory facilities made possible by grants to him from the Canadian Medical Research Council and the World Health Organization. Antisera to steroid hormones (progesterone, testosterone, oestradiol-17 $\beta$ and oestrone) were generously supplied by Dr H. R. Behrman (Yale University), Dr B. V. Caldwell (Yale University) and Dr G. D. Niswender (Colorado State University) respectively. The gonadotrophins NIH-FSH-S1 1 and NIH-LH-B8 were obtained from the Hormone Distribution Office, National Institutes of Health, Bethesda, Maryland. K.M.H. is in receipt of a Canadian M.R.C. Research Fellowship.

\section{References}

Armstrong, D.T. \& Dorrington, J.H. (1977) Estrogen biosynthesis in the ovaries and testes. In Regulatory Mechanism Affecting Gonadal Hormone Action, Vol. 3, pp. 217-258. Eds J. A. Thomas \& R. L. Singhal. University Park Press, Baltimore.

Auletta, F.J., Caldwell, B.V. \& Hamilton, G.L. (1974) Radioimmunoassay of plasma testosterone. In Methods of Hormone Radioimmunoassay, pp. 359 381. Eds B. M. Jaffe \& H. R. Behrman. Academic Press, New York.

Bjersing, L. \& Carstensen H. (1967) Biosynthesis of steroids by granulosa cells of the porcine ovary in vitro. J. Reprod. Fert. 14, 101-111.

Carr, B.R., Mikhail, G. \& Flickinger, G.L. (1971) Column chromatography of steroids on Sephadex LH-20. J. clin, Endocr. Metab. 33, 358-360.

Channing, C.P. (1969) Steroidogenesis and morphology of human ovarian cell types in tissue culture. $J$. Endocr. 45, 297-308.

Donaldson, L.E. \& Hansel, T.W. (1965) Histological study of bovine corpora lutea. J. Dairy Sci. 48, 905909.

Dorrington, J.H. \& Armstrong, D.T. (1975) Folliclestimulating hormone stimulates estradiol-17$\beta$ synthesis in cultured sertoli cells. Proc. natn. Acad. Sci. U.S.A. 72, 2677-2681.

Dorrington, J.H., Moon, Y.S. \& Armstrong, D.T. (1975) Estradiol-17 $\beta$ biosynthesis in cultured granulosa cells from hypophysectomized immature rats: stimulation by follicle-stimulating hormone. Endocrinology 97 , 1328-1331.

Dorrington, J.H., Fritz, I.B. \& Armstrong, D.T. (1976) Testicular estrogens: synthesis by isolated Sertoli cells and regulation by follicle-stimulating hormone.
In Regulatory Mechanism of Male Reproductive Physiology, pp. 63-70. Ed. C. H. Spilman. Excerpta Medica, Amsterdam.

Fortune, J.E. \& Armstrong, D.T. (1977) Androgen production by theca and granulosa isolated from proestrous rat follicle. Endocrinology 100, 1341-1347.

Fortune, J.E. \& Armstrong, D.T. (1978) Hormonal control of $17 \beta$-estradiol biosynthesis in proestrous rat follicle: estradiol production by isolated theca versus granulosa. Endocrinology 102, 227-235.

Fowler, R.E., Fox, N.L., Edwards, R.G., Walters, D.E. \& Steptoe, P.C. (1978) Steroidogenesis by cultured granulosa cells aspirated from human follicles using pregnenolone and androgens as precursors. J. Endocr. 77, 171-183.

Hammerstein, J., Rice, B.F. \& Savard, K. (1964) Steroid formation in the human ovary. I. Identification of steroids formed in vitro from ${ }^{14} \mathrm{C}$-acetate in the corpus luteum. J. clin. Endocr. Metab. 24, 597-605.

Henderson, K.M. \& Swanston, I.A. (1978) Androgen aromatization by luteinized bovine granulosa cells in tissue culture. J. Reprod. Fert. 52, 131-134.

Lacroix, E., Eechaute, W. \& Leusen, 1. (1974) The biosynthesis of estrogens by cow follicles. Steroids 23, 337-356.

Lowry, O. H., Rosebrough, N.J., Farr, A.L. \& Randall, R.J. (1951) Protein measurement with the Folin phenol reagent. J. biol. Chem. 193, 265-275.

McIntosh, E.N., Uzgiris, V.I., Alonso, C. \& Salhanick, H.A. (1971) Spectral properties, respiratory activity and enzyme systems of bovine corpus luteum mitochondria. Biochemistry, N.Y. 10, 2909-2916.

Moor, R.M. (1977) Site of steroid production in ovine Graafian follicles in culture. J. Endocr. 73, 143-150. 
Orezyk, G.P., Hichens, M., Arth, G. \& Behrman, H.R. (1974) Progesterone. In Methods of Hormone Radioimmunoassay, pp. 347-358. Eds B. M. Jaffe \& H. R. Behrman. Academic Press, New York. Savard, K. (1973) The biochemistry of the corpus luteum. Biol. Reprod. 8, 183-202.
Savard, K. \& Telegdy, G. (1965) Steroid formation in the bovine corpus luteum. Steroids 5, Suppl. II, 205210.

Watson, J. \& Leask, J.T.S. (1975) Superfusion in vitro in the study of ovarian steroidogenesis. J. Endocr. 64, 163-173.

Received 12 July 1978 